\title{
PENGARUH NET PROFIT MARGIN, RETURN ON ASSET, LIKUIDITAS TERHADAP FINANCIAL DISTRESS (Studi Kasus Pada Perusahaan Agriculture Terdaftar di Bursa Efek Indonesia Periode 2017-2019)
}

\author{
aNi Komang Yuliani, bl Nyoman Anggaradana \\ ab Universitas Pendidikan Nasional (Undiknas) Denpasar \\ akomangyuliani34@gmail.com
}

\begin{abstract}
ABSTRAK
Pengaruh Net Profit Margin, Return On Asset, Likuiditas Terhadap Financial Distress (Studi Kasus Pada Perusahaan Agriculture Terdaftar Di Bursa Efek Indonesia Periode 2017-2019). Tujuan penelitian ini untuk membuktikan pengaruh net profit margin, return on asset, likuiditas terhadap financial distress. Penelitian dilaksanakan pada sektor agriculture terdaftar di Bursa Efek Indonesia (BEI) dengan jumlah sampel 42 laporan. Metode non probability sampling melalui teknik purposive sampling digunakan untuk penentuan sampel penelitian ini. Jenis data kuantitatif diambil dari laporan tahunan maupun laporan keuangan perusahaan agriculture yang terdapat di situs resmi Bursa Efek Indonesia (BEI). Data sekunder penelitian ini hanya memanfaatkan annual report periode 2017-2019. Teknik pengumpulan data yang digunakan yaitu studi dokumentasi. Serta teknik analisis data menggunakan analisis statistik deskriptif, uji asumsi klasik, analisis linear berganda, uji hipotesis dan uji koefisien determinasi. Berdasarkan hasil analisis, secara signifikan net profit margin berpengaruh negatif terhadap financial distress, secara signifikan return on asset berpengaruh positif atas financial distress, likuiditas tidak berpengaruh dan tidak signifikan atas financial distress dan net profit margin, return on asset, likuiditas secara simultan berpengaruh signifikan atas financial distress di sektor agriculture yang tercatat di Bursa Efek Indonesia.
\end{abstract}

Kata Kunci: Net profit margin, Return on asset, Likuiditas, Financial distress, Agriculture

\begin{abstract}
The Effect of Net Profit Margin, Return On Asset, Liquidity on Financial Distress (Case Study on Agriculture Companies Listed on Indonesia Stock Exchange Period 2017-2019). The purpose of this study is to prove the influence of net profit margin, return on assets, liquidity on financial distress. The research was conducted in agriculture sector listed on Indonesia Stock Exchange (IDX) with a sample number of 42 reports. Non probability sampling method through purposive sampling technique is used for the determination of this research sample. Quantitative data types are taken from the annual report and financial statements of agriculture companies contained on the official website of the Indonesia Stock Exchange (IDX). Secondary data of this study only utilizes annual report period 2017-2019.The data collection technique used is documentation study. As well as data analysis techniques using descriptive statistical analysis, classic assumption test, multiple linear analysis, hypothesis test and determination coefficient test. Based on the results of the analysis, significantly net profit margin negatively affects financial distress, significantly return on asset positively affects financial distress, liquidity has no effect and insignificant on financial distress and net profit margin, return on asset, liquidity
\end{abstract}


simultaneously has a significant effect on financial distress in the agriculture sector listed on the Indonesia Stock Exchange.

Keywords: Net profit margin, Return on asset, Liquidity, Financial distress, Agriculture

\section{PENDAHULUAN}

Sektor agriculture merupakan karakteristik industri yang unik bergerak dalam bidang kehutanan dan bidang perkebunan. Sektor ini memiliki penyampaian informasi dalam bentuk pada laporan keuangan berupa data laporan tahunan perusahaan untuk dibandingkan dengan perusahaan di bidang lainnya. Laporan keuangan perusahaan agriculture tahun 2017-2019 merupakan salah satu bahan informasi yang berfungsi dalam pengambilan kesimpulan mengenai posisi financial perusahaan dengan cara menganalisis laporan keuangan.

Menurut (Kristanti 2019) financial distress merupakan sebagai sudut pandang ekonomi dalam pertumbuhan penjualannya. Penyebab financial distress di perusahaan agriculuture terlihat pada internal perusahaan yaitu pada bagian distribusi. Penjualan tidak sesuai dengan harapan atau produk akan menyebabkan saluran distribusi yang buruk sehingga menimbulkan kerugian perusahaan. Artinya, bahwa perusahaan dapat menghindari financial distress selama menjaga kelangsungan operasinya.

Menurut (Fahmi 2012) penanaman aset perusahaan dalam bentuk investasi untuk pengembalian keuntungan yang diharapkan ialah return on assets. Dalam menimbang efektivitas industri untuk menciptakan laba, maka aktiva yang dimiliki harus dimanfaatkan oleh perusahaan.

Rasio likuiditas merupakan kewajiban jangka pendek untuk memenuhi kemampuan perusahaan. Rasio likuiditas dihitung dengan inventory to net working capital ialah dengan membandingkan total inventory dibagi modal kerja perusahaan. Rasio likuiditas pada perkembangan masa yang akan datang dan saat ini dihitung dengan cara aset lancar dan kewajiban jangka pendek suatu perusahaan. Sehingga dapat diputuskan perusahaan dapat dikatakan baik atau sebaliknya.

(Murhadi 2013) mengatakan dalam memperoleh laba, perusahaan harus mencerminkan net profit margin dari setiap penjualannya. Dalam mengefisiensikan penggunaan bahan dan tenaga kerjanya maka perusahaan dapat menghasilkan keuntungan dalam memproduksi dan menjual produk-produknya.

Berdasarkan hal tersebut, maka dapat diringkas masalah sebagai berikut "Apakah net profit margin berpengaruh terhadap financial distress pada perusahaan agriculture yang tercatat pada Bursa Efek Indonesia rentang waktu 2017-2019?, Apakah return on asset berpengaruh terhadap financial distress pada perusahaan agriculture yang tercatat pada Bursa Efek Indonesia rentang waktu 2017-2019, Apakah likuiditas berpengaruh terhadap financial distress pada perusahaan agriculture yang tercatat pada Bursa Efek Indonesia rentang waktu 2017-2019?, Apakah net profit margin, return on asset, likuiditas berpengaruh terhadap financial distress pada perusahaan agriculture yang tercatat pada Bursa Efek Indonesia rentang waktu 2017-2019?.

\section{KAJIAN LITERATUR}

\section{Teori Sinyal}

Teori sinyal mengelaskan bagian eksternal diberikan dorongan oleh pihak perusahaan dalam pemberian informasi laporan keuangan. Menurut (Sri Rahayu 2010) dengan membagikan penjelasan mengenai financial yang bisa dipercaya, akan dapat memangkas perspektif industri dimasa mendatang. 
Asumsi utama pada teori sinyal ini yaitu untuk memberikan ruang kepada investor berkaitan dengan net profit margin tersebut. Akibatnya, ketika net profit margin, return asset, likuiditas dimasa yang akan datang dapat memprediksi adanya potensi kebangrutan pada perusahaan. Hal ini memberikan informasi pada investor untuk memberikan penilaian terhadap perusahaan.

\section{Financial Distress}

Financial distress ialah kepelikan financial industri dan terancam bangkrut, akibatnya untuk memperoleh laba perusahahaan gagal dalam menjalankan operasi perusahaan.

Untuk memperkirakan financial distress atas telaah eksperimen menggunakan model Springate. Springate memperkenalkan persamaan ini yaitu.

$$
Z=1.03 \mathrm{~A}+3.07 \mathrm{~B}+0.66 \mathrm{C}+0.4 \mathrm{D}
$$

\section{Net Profit Margin}

Net profit margin menggambarkan industri yang memperoleh laba dari setiap penjualannya. Bagi investor, perbandingan laba bersih atas total penjualan dapat mengukur dengan rasio net profit margin untuk mengetahui seberapa efesien manajemen mengelola perusahaannya. Rumus perhitungan net profit margin yaitu.

Net Profit Margin $=\frac{\text { Earning After Tax }(E A T)}{\text { Sales }} \times 100 \%$

\section{Return On Asset (ROA)}

Return on assets merupakan aset perusahaan yang ditanamkan dalam bentuk investasi untuk pengembalian keuntungan yang diharapkan. Karena dalam mengevaluasi ROA digunakan seberapa baik dana perusahaan telah dipakai. Semakin semampai ROA maka semakin normal manajemen perusahaan yang dapat digambarkannnya. Karena untuk menghasilkan pendapatan yang optimal, perusahaan harus mengelola aktiva. Return on assets memiliki rasio industri yaitu 30\% (Kasmir 2017).

$$
\text { Return On Asset }=\frac{\text { Laba Bersih Setelah Pajak }}{\text { Total Asset }} \times 100 \%
$$

\section{Likuiditas}

Fungsi rasio likuiditas menunjukan kewajiban terhadap bagian likuiditas badan usaha maupun likuiditas perusahaan yang sudah jatuh tempo, (Kasmir 2017). Macam-macam rasio likuiditas yaitu current ratio, quick ratio, inventory to net working capital, cash flow likuidity ratio. Salah satu rasio likuiditas yang dipakai pada penelitian ini adalah inventory to net working capital yaitu membagi jumlah persediaan dengan current asset dikurangi dengan current liabilities. Inventory to net working capital memiliki rata-rata industri yaitu $12 \%$.

$$
\text { Inventory to } N W C=\frac{\text { Inventory }}{\text { Current Asset - Current Liabilities }} \times 100 \%
$$

\section{Pengaruh Net Profit Margin terhadap Financial Distress}

Net profit margin menunjukkan laba bersih sesudah dikurangi pembayaran pungutan untuk menghasilkan laba bersih perusahaan. Untuk menunjukkan peringkat kepercayaan investor yang kian tinggi, maka industri harus mampu didalam situasi yang produktif agar kecil kemungkinan terjadinya financial distress di perusahaan.

H1: Net Profit Margin berpengaruh atas Financial Distress.

\section{Pengaruh Return On Asset terhadap Net Profit Margin}

Return On Asset (ROA) digunakan dalam mengevaluasi dana yang telah dipakai oleh perusahaan. Semakin semampai return on asset, manajemen industri akan terlihat semakin berkualitas. Sebab pendapatan yang optimal merupakan aktiva yang dikelola dengan menghasilkan. Dalam memperoleh laba, maka perusahaan harus mempertahankan return on asset agar menunjukkan angka yang positif. 
H2: Return On Asset berpengaruh atas Financial Distress.

\section{Pengaruh Likuiditas terhadap Financial Distress}

Rasio likuiditas merujuk pada inventory to net working capital pengukuran dengan menggunakan jumlah persediaan yang ada berbanding modal kerja perusahaan. Industri dapat dikatakan likuid jika aktiva lancar perusahaan lebih besar dari pada utang lancar, H3: Likuiditas berpengaruh atas Financial Distress.

\section{Pengaruh Net Profit Margin, Return On Asset, Likuiditas terhadap Financial Distress}

Semakin besar tingkat kepercayaan investor, maka akan dianggap perusahaan semakin produktif. Sehingga menunjukan semakin kecil net profit margin perusahaan maka semakin kecil peluang financial distress.

Dalam pengambilan keputusan oleh pemangku kepentingan bersandarkan keleluasaan perihal financial distress oleh perusahaan yang memberikan informasi jumlah aset saat ini yang dimiliki perusahaan mampu menunjukkan angka positif.

Rasio likuiditas merujuk pada inventory to net working capital. Perusahaan dikatakan likuid apabila perusahaan mempunyai lebih besar aktiva lancar dari pada utang lancar, hal ini dijadikan pengambilan keputusan investasi untuk informasi bagi stakeholder.

H4: Net Profit Margin, Return On Asset, Likuiditas berpengaruh atas Financial Distress.

\section{METODE}

Lokasi telaah eksperimen bertempat pada sektor agriculture tercatat di Bursa Efek Indonesia (BEI). Dipilihnya perusahaan agriculture dijadikan tempat ekperimen dikarenakan sektor agriculture mampu bertahan di tengah kondisi perekonomian Indonesia, sehingga prospek yang diharapkan dapat menguntungkan dan memenuhi kebutuhan masyarakat. Penelitian ini memakai 21 populasi. Sampel yang dipakai sejumlah 42 laporan. Pengambilan sampel dilipih memakai teknik pemilihan non probability sampling, melalui teknik purposive sampling. Jenis data kuantitatif dengan bentuk data sekunder yang didapat dari situs resmi Bursa Efek Indonesia (BEI) dengan bentuk annual report periode 2017-2019. Teknik pengumpulan data menggunakan studi dokumentasi. Dan teknik analisis data yang dipakai yaitu analisis statistik deskriptif, uji asumsi klasik, analisis linear berganda, uji hipotesis dan uji koefisien determinasi.

\section{HASIL DAN PEMBAHASAN}

\section{Analisis Data Hasil Uji Statistik Deskriptif}

Statistik Deskriptif Data Penelitian Descriptive Statistics

\begin{tabular}{|l|r|r|r|r|r|}
\hline & $\mathrm{N}$ & Minimum & Maximum & \multicolumn{1}{c|}{ Mean } & Std. Deviation \\
\hline Net Profit Margin & 42 & -1.52 & .24 & -.0705 & .29981 \\
Return On Asset & 42 & -.30 & .15 & .0092 & .07652 \\
Likuiditas & 42 & -3.03 & 39.37 & 1.9535 & 7.01408 \\
Financial Distress & 42 & .00 & 2.54 & .8374 & .69411 \\
Valid N (listwise) & 42 & & & & \\
\hline
\end{tabular}

Sumber: Data diselesaikan, 2020

Tabel diatas menunjukan bahwa jumlah data (Valid N) yang ada pada penelitian ini sebanyak 42 sampel yang berasal dari 14 laporan tahunan perusahaan diterbitkan oleh industri agriculture tercatat di Busa Efek Indonesia (BEI) selama 3 rentang waktu 2017 sampai dengan 2019. 


\section{Hasil Uji Asumsi Klasik Uji Multikolinearitas}

\section{Hasil Uji Multikolinearitas}

\begin{tabular}{|c|c|c|c|c|c|c|c|}
\hline \multirow[b]{2}{*}{ Model } & \multicolumn{2}{|c|}{$\begin{array}{l}\text { Unstandardized } \\
\text { Coefficients }\end{array}$} & \multirow{2}{*}{$\begin{array}{c}\begin{array}{c}\text { Standa } \\
\text { rdized } \\
\text { Coeffic } \\
\text { ients }\end{array} \\
\text { Beta }\end{array}$} & \multirow[t]{2}{*}{$\mathrm{T}$} & \multirow[t]{2}{*}{ Sig. } & \multicolumn{2}{|c|}{$\begin{array}{l}\text { Collinearity } \\
\text { Statistics }\end{array}$} \\
\hline & B & $\begin{array}{l}\text { Std. } \\
\text { Error }\end{array}$ & & & & $\begin{array}{c}\text { Toleran } \\
\text { ce }\end{array}$ & VIF \\
\hline 1 (Constant) & .540 & .084 & & 6.403 & .000 & & \\
\hline $\begin{array}{l}\text { Net Profit } \\
\text { Margin }\end{array}$ & -2.142 & .546 & -.925 & -3.923 & .000 & .138 & 7.264 \\
\hline $\begin{array}{l}\text { Return On } \\
\text { Asset }\end{array}$ & 3.646 & 2.144 & 1.615 & 6.830 & .000 & .137 & 7.298 \\
\hline Likuiditas & .006 & .009 & .062 & .696 & .491 & .969 & 1.032 \\
\hline
\end{tabular}

a. Dependent Variable: Financial Distress

Sumber: Data diselesaikan, 2020

Berdasarkan output SPSS pada tabel 4.2 dapat diprediksi bahwa diperoleh nilai tolerance dari seluruh variabel sebesar $0.138,0.137,0.969$ yang kesemuanya diatas 0.1 , dan nilai VIF sebesar 7.264, 7.298, 1.032 yang kesemua nilai VIF dibawah 10. Hal ini menunjukan model regresi tersebut lolos uji multikolinearitas antar variabel independen.

\section{Uji Autokorelasi}

\section{Hasil Uji Autokorelasi}

\begin{tabular}{|c|c|c|c|c|c|}
\hline \multicolumn{6}{|c|}{ Model Summary } \\
\hline Model & $\mathrm{R}$ & R Square & $\begin{array}{l}\text { Adjusted R } \\
\text { Square }\end{array}$ & $\begin{array}{l}\text { Std. Error of the } \\
\text { Estimate }\end{array}$ & Durbin-Watson \\
\hline 1 & $.842^{2}$ & .709 & .686 & .38892 & 2.488 \\
\hline
\end{tabular}

Sumber: Data diselesaikan, 2020

Dalam pengambilan keputusan diatas, dapat disimpulkan nilai durbin watson berarti tidak terdapat autokorelasi.

\section{Uji Heteroskedastisitas}

\section{Hasil Uji Heteroskedastisitas}

Scatterplot

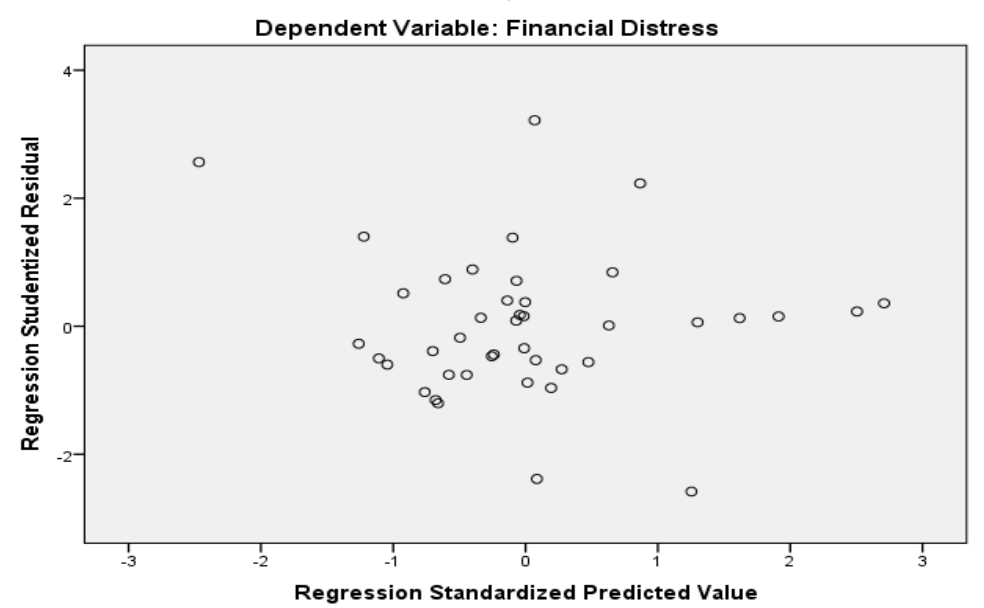

Sumber: Data diselesaikan, 2020

Berdasarkan tabel 4.4 dapat ditunjukan bahwa, model scatterplot tidak mengandung gejala heteroskedastisitas. Karena titik-titik menyebar diatas dan dibawah angka 0 pada sumbu $Y$. 


\section{Hasil Analisis Linear Berganda}

\section{Hasil Analisis Linear Berganda}

\begin{tabular}{|c|c|c|c|c|c|c|}
\hline \multicolumn{7}{|c|}{ Coefficients ${ }^{\mathrm{a}}$} \\
\hline \multirow{2}{*}{\multicolumn{2}{|c|}{ Model }} & \multicolumn{2}{|c|}{ Unstandardized Coefficients } & $\begin{array}{l}\text { Standardized } \\
\text { Coefficients }\end{array}$ & \multirow[b]{2}{*}{$T$} & \multirow[b]{2}{*}{ Sig. } \\
\hline & & B & Std. Error & Beta & & \\
\hline \multirow[t]{4}{*}{1} & (Constant) & .540 & .084 & & 6.403 & .000 \\
\hline & Net Profit Margin & -2.142 & .546 & -.925 & -3.923 & .000 \\
\hline & Return On Asset & 14.646 & 2.144 & 1.615 & 6.830 & .000 \\
\hline & Likuiditas & .006 & .009 & .062 & .696 & .491 \\
\hline
\end{tabular}

Sumber: Data diselesaikan, 2020

Berdasarkan tabel 4.5 maka persamaan regresi yang digunakan pada penelitian ini adalah sebagai berikut.

$\mathrm{Y}=0.540-2.142 \mathrm{X}_{1}-14.646 \mathrm{X}_{2}+0.006 \mathrm{X}_{3}$

Keterangan:

$\mathrm{Y}=$ Financial Distress

$\mathrm{X}_{1}=$ Net Profit Margin

$\mathrm{X}_{2}=$ Return On Asset

$\mathrm{X}_{3}=$ Likuiditas

\section{Hasil Uji Hipotesis \\ Uji t}

\begin{tabular}{|c|c|c|c|c|c|}
\hline \multicolumn{6}{|c|}{$\begin{array}{l}\text { Hasil Uji T } \\
\text { Coefficients }^{\text {a }}\end{array}$} \\
\hline \multirow[b]{2}{*}{ Model } & \multicolumn{2}{|c|}{ Unstandardized Coefficients } & $\begin{array}{c}\text { Standardized } \\
\text { Coefficients }\end{array}$ & $\mathrm{t}$ & Sig. \\
\hline & B & Std. Error & Beta & & \\
\hline 1 (Constant) & .540 & .084 & & 6.403 & .000 \\
\hline Net Profit Margin & -2.142 & .546 & -.925 & -3.923 & .000 \\
\hline Return On Asset & 14.646 & 2.144 & 1.615 & 6.830 & .000 \\
\hline Likuiditas & .006 & .009 & .062 & .696 & .491 \\
\hline
\end{tabular}

a. Dependent Variable: Financial Distress

Sumber: data diselesaikan, 2020

1. Pengaruh Net Profit Margin terhadap Financial Distress

Variabel net profit margin $\left(\mathrm{X}_{1}\right)$ terhadap financial distress $(\mathrm{Y})$ diperoleh nilai signifikan sebesar 0.000 dengan nilai koefisien regresi negative sebesar -2.142 . Hal ini dapat dibuktikan dari hasil signifikansi 0.000 lebih kecil dari 0.05 , sedangkan t table melalui signifikansi 0.05 dengan derajat keabsahan $(\mathrm{df}=\mathrm{n}-\mathrm{k})$ atau $(\mathrm{df}=42-3=39)$ dan diperoleh $\mathrm{t}$ table sebesar 1.68488. Artinya t hitung -3.923 .

2. Pengaruh Return On Asset terhadap Financial Distress

Variabel return on asset $\left(\mathrm{X}_{2}\right)$ terhadap financial distress $(\mathrm{Y})$ diperoleh nilai signifikan sebesar 0.000 dengan nilai koefisien regresi positif sebesar 14.646. Hal ini dapat dibuktikan dari hasil signifikansi 0.000 lebih kecil dari 0.05 , sedangkan $t$ table dengan signifikansi 0.05 dengan derajat keabsahan ( $\mathrm{df}=\mathrm{n}-\mathrm{k}$ ) atau ( $\mathrm{df}=42-3=39$ ) dan ditemukan $t$ table sebesar 1.68488. Artinya t hitung 6.830.

3. Pengaruh Likuiditas terhadap Financial Distress

Variabel likuiditas $(\mathrm{X})$ terhadap financial distress $(\mathrm{Y})$ diperoleh nilai signifikan sebesar 0.491 dengan nilai koefisien regresi positif sebesar 0.006. Hal ini dapat dibuktikan dari hasil signifikansi 0.491 lebih besar dari 0.05 , sedangkan t table dengan signifikansi 0.05 
dengan derajat keabsahan $(\mathrm{df}=\mathrm{n}-\mathrm{k})$ atau $(\mathrm{df}=42-3=39)$ dan ditemukan t table sebesar 1.68488. Artinya t hitung 0.696 .

Uji F

\begin{tabular}{|c|c|c|c|c|c|c|}
\hline \multicolumn{7}{|c|}{$\begin{array}{c}\text { Hasil Uji F } \\
\text { ANOVA }^{\mathrm{a}}\end{array}$} \\
\hline & & Sum of Squares & $\mathrm{Df}$ & Mean Square & $\mathrm{F}$ & Sig. \\
\hline \multirow[t]{3}{*}{1} & Regression & 14.005 & 3 & 4.668 & 30.864 & $.000^{\mathrm{b}}$ \\
\hline & Residual & 5.748 & 38 & .151 & & \\
\hline & Total & 19.753 & 41 & & & \\
\hline
\end{tabular}

Sumber: Data diselesaikan, 2020

Hasil ini memberikan makna bahwa net profit margin, return on asset, likuiditas tepat memprediksi dan menjelaskan fenomena financial distress pada perusahaan agriculture pada Bursa Efek Indonesia. Artinya, dalam memproyeksikan model hasil data panelnya baik dengan nilai $F$ hitung adalah 30.864 dengan nilai signifikansi $P$ value 0.000 .

Hasil Uji Koefisien Determinasi $\left(\mathbf{R}^{2}\right)$

Uji $\mathbf{R}^{2}$

Model Summary

\begin{tabular}{|l|c|r|r|c|}
\hline Model & R & R Square & $\begin{array}{c}\text { Adjusted R } \\
\text { Square }\end{array}$ & $\begin{array}{c}\text { Std. Error of the } \\
\text { Estimate }\end{array}$ \\
\hline 1 & $.842^{\mathrm{a}}$ & .709 & .686 & .38892 \\
\hline
\end{tabular}

a. Predictors: (Constant), Likuiditas, Net Profit Margin , Return On

Asset

b. Dependent Variable: Financial Distress

Sumber: Data diselesaikan, 2020

Rumus untuk menentukan besarnya koefisien determinasi yaitu $D=R^{2} \times 100 \%$, berdasarkan table 4.7 diketahui nilai $\left(R^{2}\right)=0.709$ maka,

$\mathrm{D}=0.709 \times 100 \%$

$=70.9 \%$

Berdasarkan hasil tersebut diketahui nilai $\left(\mathrm{R}^{2}\right)=70.9 \%$, artinya net profit margin, return on asset, dan likuiditas mempengaruhi financial distress sebesar $70.9 \%$. Sedangkan sisanya sebesar $29.1 \%$ dipengaruhi oleh variable lain yang tidak dianalisis dalam peneltian ini.

\section{Pembahasan}

\section{Pengaruh Net Profit Margin terhadap Financial Distress}

Laba neto dari setiap penjualannya merupakan cerminan kemampuan perusahaan untuk mengetahui net profit margin. Rendahnya net profit margin karena kurangnya efisiensi manajemen untuk menekan biaya-biaya yang dapat mengurangi jumlah laba bersih. Kondisi seperti ini masuk kedalam situasi financial distress yang menyebabkan terjadinya probabilitas kebangrutan. Hal ini dikarenakan internal perusahaan mempersulit sumber pendanaan keuangan untuk investasi (Amir Saleh 2013). Kesulitan keuangan merupakan keadaan financial prusahaan dalam kondisi yang tidak sehat.

Berdasarkan hasil koefisien regresi secara signifikan net profit margin berpengaruh negatif terhadap financial distress. Hal ini berarti apabila net profit margin semakin tinggi, maka terjadinya financial distress semakin mengalami rendah. Adapun persamaan regresi linear berganda adalah sebagai berikut: $Y=0.540-2.142 X_{1}-14.646 X_{2}+0.006 X_{3}$. Hal ini menunjukan bahwa koefisien regresi return on asset sebesar -2.142 menunjukan bahwa setiap penurunan net profit margin senyampang satu satuan mengenai terjadinya penurunan financial distress sebesar -2.142 satuan. $\mathrm{H}_{1}$ Secara signifikan net profit margin 
berpengaruh negatif terhadap financial distress dapat diterima, yaitu semakin perusahaan mampu memanajemen untuk menghasilkan pendapatan maka perusahaan semakin perusahaan terhindar dari financial distress. Nilai signifikan sebesar $0.496>0.05$ mengidentifikasi bahwa secara signifikan net profit margin berpengaruh negatif atas financial distress.

\section{Pengaruh Return On Asset Terhadap Financial Distress}

Return on assets merupakan aset perusahaan yang ditanamkan dalam bentuk investasi untuk pengembalian keuntungan yang diharapkan. Return on asset yang tinggi dapat menilai kualitas dan kinerja perusahaan untuk menghasilkan laba bersih sehingga return on asset ini tidak akan masuk kedalam situasi financial distress. Sebaliknya, financial distress paling besar terjadi ketika kondisi perusahaan tidak dapat diatasi dengan baik (Hanifah, Oktita Earning, Purwanto 2013).

Berdasarkan hasil koefisien secara signifikan regresi return on asset berpengaruh positif atas financial distress. Keadaan ini berarti apabila financial distress mengalami penurunan maka return on asset semakin mengalami peningkatan. Adapun persesuaian regresi linear berganda yaitu sebagai berikut: $Y=0.540-2.142 X_{1}-14.646 X_{2}+0.006 X_{3}$. Hal ini, koefisien regresi menunjukan bahwa return on asset sebesar 14.646 menunjukan bahwa setiap kenaikan return on asset sebesar 1 satuan akan terjadi penurunan financial distress. $\mathrm{H}_{2}$ secara signifikan return on asset berpengaruh positif terhadap financial distress dapat diterima, yaitu semakin perusahaan dapat menghindari financial distress maka perusahaan dikatakan mampu menghasilkan laba dari penggunaan seluruh sumber daya atau aset yang dimilikinya. Nilai signifikan sebesar $0.000>0.05$ mengidentifikasi bahwa secara signifikan variable return on asset berpengaruh positif atas financial distress.

\section{Pengaruh Likuiditas Terhadap Financial Distress}

Likuiditas merupakan kewajiban jangka pendek untuk memenuhi kemampuan perusahaan. Rasio likuiditas dihitung dengan inventory to net working capital ialah rasio untuk mengibaratkan jumlah persediaan terhadap modal kerja perusahaan. Kondisi kesulitan keuangan dalam perusahaan dilihat dari cenderungnya rasio likuiditas yang tinggi. Oleh karena itu, financial distress berpengaruh terhadap yang menjadi salah satu faktor yang memiki pengaruh tinggi yaitu rasio likuiditas.

Berdasarkan hasil koefisien regresi likuiditas tidak berpengaruh dan tidak signifikan terhadap financial distress. Hal ini bermakna apabila likuiditas semakin mengalami peningkatan, maka mengakibatkan financial distress semakin mengalami peningkatan pula. Adapun persamaan regresi linear berganda adalah sebagai berikut: $Y=0.540-2.142 X_{1}$ $14.646 \mathrm{X}_{2}+0.006 \mathrm{X}_{3}$. Hal ini mengartikan bahwa koefisien regresi likuiditas sebesar 0.006 menunjukan bahwa setiap kenaikan likuiditas sebesar 1 satuan akan terjadi kenaikan financial distress. Hasil penelitian yang dilakukan di perusahaan agriculture yang terdaftar di Bursa Efek Indonesia ditemukan bahwa $\mathrm{H}_{3}$ ditolak, karena menunjukkan rasio likuiditas tidak berpengaruh terhadap financial distress.

\section{Pengaruh Net Profit Margin, Return On Asset, Likuiditas Terhadap Financial Distress}

Secara simultan koefisien regresi variable pada pengkajian ini ialah net profit margin, return on asset, likuiditas berpengaruh signifikan atas financial distress. Setelah dilakukan pemeriksaan koefisien regresi secara simultan, berdasarkan table ANOVA terlihat pada hasil uji $F$ nilai signifikan sebesar 0.000 yang lebih kecil dari signifikansi 0.05 . Ini berarti hasil uji $F$ menunjukan net profit margin, return on asset, likuiditas secara simultan memiliki pengaruh signifikan terhadap variable dependen yaitu financial distress. Seberapa besar kemapuan variable independent dalam menggambarkan financial distress maka digarap uji koefisien determinasi. Dan hasil uji koefisien determinasi menunjukan bahwa variable independent mampu menjelaskan financial distress sebesar $70.9 \%$. Sedangkan senyampang sebesar $29.1 \%$ dipengaruhi oleh variable lain. Dengan hasil tersebut, maka $\mathrm{H}_{4}$ diterima. Berdasarkan uji t diatas pada table koefisien standardized oefficient kesimpulan yang dapat ditarik yaitu, rasio return on asset dominan berpengaruh atas financial distress dengan taraf 1.615. 


\section{SIMPULAN}

\section{Simpulan}

Simpulan yang dapat diberikan pada penelitian ini yaitu:

1. Net profit margin berpengaruh negatif dan signifikan atas financial distress. Jadi apabila net profit margin menunjukan bahwa semakin tinggi terjadinya financial distress semakin rendah di sektor agriculture tercatat di Bursa Efek Indonesia. Memakai hasil tersebut maka $\mathrm{H}_{1}$ diterima.

2. Return on asset berpengaruh positif dan signifikan atas financial distress. Jadi apabila return on asset menandakan bahwa untuk terhindarnya dari financial distress semakin tinggi di sektor agriculture yang tercatat di Bursa Efek Indonesia. Dengan menggunakan hasil tersebut, maka $\mathrm{H}_{2}$ diterima.

3. Likuiditas tidak berpengaruh dan tidak signifikan atas financial distress. Jadi apabila likuiditas menunjukan semakin tinggi, maka kemungkinan terjadinya financial distress semakin tinggi pula di sektor agriculture tercatat di Bursa Efek Indonesia. Dapat dikatakan hasil tersebut maka, $\mathrm{H}_{3}$ ditolak.

4. Net profit margin, return on asset, likuiditas secara simultan berpengaruh signifikan atas financial distress di sektor agriculture tercatat di Bursa Efek Indonesia. Maka hasil tersebut $\mathrm{H}_{4}$ diterima.

\section{Saran}

Penelitian ini dapat diberikan saran yaitu.

1. Bagi peneliti selanjutnya disarankan memakai rentang waktu lebih dari 3 tahun dan variable penelitian agar memberikan gambaran kondisi financial distress secara lebih luas dengan menggunakan alat ukur yang lain.

2. Bagi perusahaan, sebaiknya meningkatkan dan memperhatikan kembali penyajian laporan keuangan. Dengan meningkatnya penjualan perusahaan, maka industri dapat terlepas dari terjadinya financial distress. Serta metode yang seharusnya dipergunakan dan diinginkan investor dapat mengamanatkan investasinya ke perusahaan tersebut untuk mengurangi risiko keuangan perusahaan.

3. Bagi pemerintah sebagai regulator diperlukan mampu membantu kemajuan perusahaan agriculture dengan prosedur serta kewenangannya.

\section{REFERENSI}

Amir Saleh, Bambang Sudiyatno. 2013. "Pengaruh Rasio Keuangan Untuk Memprediksi Probabilitas Kebangkrutan Pada Perusahaan Manufaktur Yang Terdaftar Di Bursa Efek Indonesia." Dinamika Akuntansi Keuangan Dan Perbankan 2: 82-91. https://www.unisbank.ac.id/ojs/index.php/fe9/article/view/2109.

Fahmi, Irhan. 2012. Pengantar Manajemen Keuangan Teori Dan Soal Jawab. Edited by Muslim A. Djalil. Bandung: CV Alfabeta.

Hanifah, Oktita Earning, Purwanto, Agus. 2013. "Pengaruh Struktur Corporate Governance Dan Financial Indicators Terhadap Kondisi Financial Distress." Diponegoro Journal Of Accounting 2: 648-62.

Kasmir. 2017. Analisis Laporan Keuangan. Jakarta: PT Raja Grafindo Persada.

Kristanti, Farida Titik. 2019. Financial Distress (Teori Dan Perkembangannya Dalam Konteks Indonesia). I, 2019. Malang: Inteligensia Media.

Murhadi, Werner R. 2013. Analisis Laporan Keuangan, Proyeksi Dan Valuasi Saham. Jakarta: Salemba Empat.

Sri Rahayu. 2010. "Pengaruh Kinerja Keuangan Terhadap Nilai Perusahaan Dengan Pengungkapan Corporate Social Responsibility Dan Good Corporate Goveranance Sebagai Variabel Pemoderasi (Studi Empiris Pada Perusahaan Manufaktur Di Bursa Efek Jakarta)." http://eprints.undip.ac.id/23232/. 